\title{
Osteoclastoma-Like Giant Cell Tumor of the Liver, an Extremely Rare
}

\section{Tumor}

\author{
Bita Geramizadeh, ${ }^{1,2, *}$ and Kurosh Kazemi ${ }^{3}$ \\ ${ }^{1} \mathrm{MD}$, Department of Pathology \\ ${ }^{2}$ Transplant Research Center \\ ${ }^{3} \mathrm{MD}$, Hepatobiliary and liver Transplant Surgery \\ "Corresponding author: Bita Geramizadeh, Department of Pathology, Transplant Research Center, Shiraz University of Medical Sciences, Shiraz, Iran. Tel: +98-7136473238, \\ E-mail: geramib@gmail.com
}

Received 2017 April 02; Revised 2017 September 02; Accepted 2017 September 06.

\begin{abstract}
Giant cell rich hepatic tumors are divided into two types of mesenchymal and epithelial. Mesenchymal tumors are uncommon. Osteoclastoma-like giant cell tumor of the liver is an extremely rare mesenchymal hepatic tumor with very poor prognosis. To the best of our knowledge, only 5 cases have been reported in the English literature so far. Our case was a 64-year-old woman presented with abdominal pain. The patient was operated with the preoperative imaging diagnosis of angiosarcoma that after pathologic examination turned out to be osteoclastoma-like giant cell tumor. Unfortunately, the patient died shortly after surgery.
\end{abstract}

\section{Introduction}

Giant cell tumors are mesenchymal neoplasms primarily seen in bone and soft tissues; but they have also been rarely reported from other organs such as thyroid, gall bladder, and pancreas (1). Occurrence of this type of tumor in the liver is an extremely rare event and to the best of our knowledge, only 5 cases have been reported in the English literature (2-5). Herein, we report our experience with an aggressive giant cell rich non-epithelial mesenchymal tumor in the liver (osteoclastoma-like giant cell tumor) in a 64-year-old female as the 6th case in the English literature.

\section{Case Report}

A 64-year-old woman presented with abdominal pain. Her past medical history was unremarkable. Her physical examination was also unremarkable. The heart and the lung were normal. There was no hepatomegaly or splenomegaly in abdominal examination. The head and neck examinations were also normal.

Laboratory examination showed $\mathrm{WBC}=9000 / \mathrm{mL}, \mathrm{Hb}=$ $13 \mathrm{~g} / \mathrm{dL}$, and platelet $=250,000 / \mathrm{mL}$. ALT, AST, GGT, and alkaline phosphates were all unremarkable. Tumor markers of CEA, CA125, and CA19-9 were all in normal range.

Abdominal sonography showed a liver mass. CT scan showed an enlarged liver with a large mass in the right lobe of the liver with irregular borders and central necrosis, measuring $20 \mathrm{~cm}$ in the greatest diameter. A few smaller lesions were also present. Portal vein thrombosis was also identified. Non-tumoral liver was unremarkable, meaning that there was no underlying disease in the non-tumoral liver parenchyma (Figure 1).

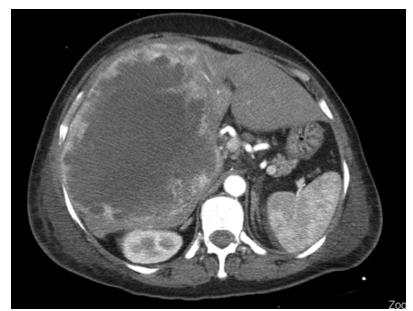

Figure 1. A Huge Mass in the Right Lobe of the Liver

The patient was scheduled for surgery with the preoperative imaging diagnosis of angiosarcoma. In the operation, the mass was reported to be hypervascular by the surgeon and the surgeon's diagnosis was angiosarcoma. Incisional biopsy was performed. The received specimen in the pathology lab was fragmented, brown, and full of blood, measuring totally $4 \mathrm{X} 3 \mathrm{X} 1 \mathrm{~cm}^{3}$.

Microscopic sections showed bloody background with many osteoclast-like giant cells intermingled with mononuclear cells (Figure $2 \mathrm{~A}$ ), which were reactive with CD68 and vimentin (Figure 2B) but nonreactive with all the epithelial markers. The histopathologic findings were very similar to giant cell tumor of the bone. Many mitotic figures were present in the atypical pleomorphic mononuclear cells, with high Ki67 (Figure 2C).

After surgery, the patient had an uneventful postoperative period; however, in less than 2 months she died of cardiorespiratory arrest. 


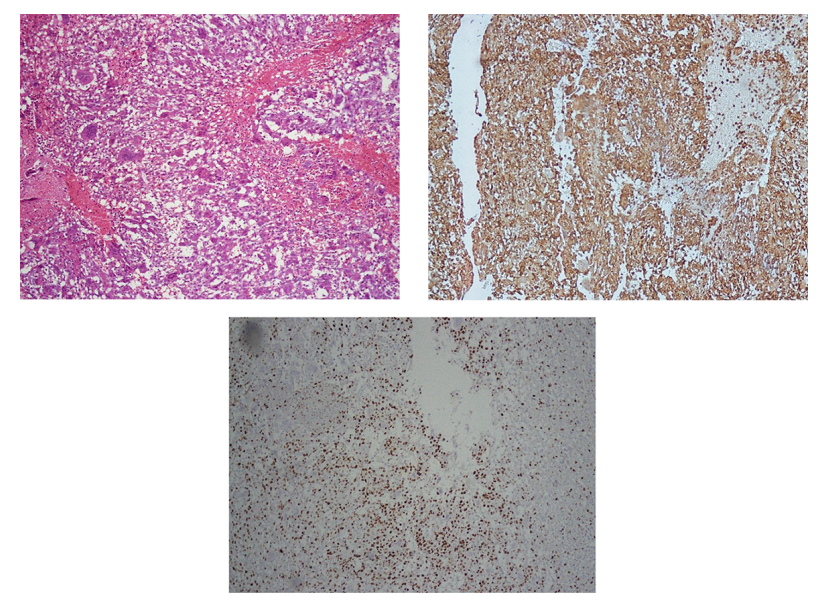

Figure 2. A, Histologic Sections Show Hemorrhagic Tissue with Many Giant Cells and Mononuclear Cells (H\&EX250); B, IHC Sections Show Reactive Vimentin; C, IHC Sections Show High Ki67

\section{Discussion}

Osteoclastoma-like giant cell tumor of the liver is an extremely rare tumor in the liver so that only 5 cases have been reported in the English literature since 1980. Table 1 shows the characteristics of the above-mentioned 5 cases. The first case was reported by Munoz in 1980 (1). All of the reported patients including ours were older than 50 years. It does not seem to have any sex preferences, and it is equally distributed in females and males. All of the previously reported cases, except two, have been in the liver with no underlying disease. The first reported case in 1980 by Munoz was observed in a patient with alcoholic cirrhosis who presented symptoms of portal hypertension (1). The other case autopsied and reported by Zhang was also a cirrhotic patient with no definite cause (5).

The most common presenting symptom has been abdominal pain; however, as the table shows, one case was incidentally detected (4).

In all non-cirrhotic cases, liver function tests and tumor markers have been in normal range and therefore, seem to have no diagnostic value (1-5).

All of the reported tumors have been hemorrhagic, which has been misdiagnosed as angiosarcoma before pathologic diagnosis (2).

Microscopic examination has been the same in all the 6 cases including osteoclast-like giant cells with abundant eosinophilic cytoplasm and a variable number of nuclei, mixed with malignant pleomorphic mononuclear cells and hemorrhagic background. The most important point in histopathology of this tumor is the differential diagnosis of hepatocellular carcinoma rich in osteoclast like giant cells, which shows positive epithelial markers instead

\begin{tabular}{|c|c|c|c|c|c|c|c|}
\hline Author & $\begin{array}{l}\text { Year Re- } \\
\text { ported }\end{array}$ & Age, $y$ & Sex & $\begin{array}{l}\text { Clinical } \\
\text { Presen- } \\
\text { tation }\end{array}$ & Size, $\mathrm{cm}$ & Outcome & $\begin{array}{l}\text { Underlying } \\
\text { liver } \\
\text { disease }\end{array}$ \\
\hline Munoz1 & 1980 & 87 & M & $\begin{array}{l}\text { Portal } \\
\text { Hyper- } \\
\text { tension }\end{array}$ & 11 & $\begin{array}{l}\text { Died } 32 \\
\text { days after } \\
\text { opera- } \\
\text { tion }\end{array}$ & $\begin{array}{l}\text { Alcoholic } \\
\text { Cirrhosis }\end{array}$ \\
\hline Horie 2 & 1987 & 66 & $\mathrm{~F}$ & $\begin{array}{l}\text { Hematoeme: } \\
\text { Nausea; } \\
\text { Abdomi- } \\
\text { nal } \\
\text { pain }\end{array}$ & 5 & $\begin{array}{l}\text { Died in } \\
42 \text { days } \\
\text { after op- } \\
\text { eration }\end{array}$ & - \\
\hline Rudloff3 & 2005 & 61 & $\mathrm{~F}$ & $\begin{array}{l}\text { Right } \\
\text { upper } \\
\text { quadrant } \\
\text { pain }\end{array}$ & 8 & $\begin{array}{l}\text { Died } \\
\text { after car- } \\
\text { diorespi- } \\
\text { ratory } \\
\text { failure }\end{array}$ & - \\
\hline $\begin{array}{l}\text { Bau- } \\
\text { ditz4 }\end{array}$ & 2006 & 54 & M & Incidental & 7 & $\begin{array}{l}\text { Died } \\
\text { after } 15 \\
\text { months }\end{array}$ & . \\
\hline Zhang5 & 2006 & 65 & M & $\begin{array}{l}\text { Right } \\
\text { upper } \\
\text { quadrant } \\
\text { pain }\end{array}$ & 13 & $\begin{array}{l}\text { Died } \\
\text { after } 5 \\
\text { days of } \\
\text { hypov- } \\
\text { olemic } \\
\text { shock }\end{array}$ & Cirrhosis \\
\hline $\begin{array}{l}\text { Current } \\
\text { Case }\end{array}$ & 2017 & 64 & $\mathrm{~F}$ & $\begin{array}{l}\text { Abdominal } \\
\text { pain }\end{array}$ & 20 & $\begin{array}{l}\text { Died } \\
\text { after car- } \\
\text { diorespi- } \\
\text { ratory } \\
\text { arrest }\end{array}$ & - \\
\hline
\end{tabular}

of mesenchymal (6). These tumors, which have most commonly been reported in pancreas, sometimes have typical areas of carcinoma (7).

All of the previously reported cases of osteoclastomalike giant cell tumor of the liver expired shortly after surgery, indicating that the disease has a very poor prognosis.

\section{References}

1. Munoz PA, Rao MS, Reddy JK. Osteoclastoma-like giant cell tumor of the 
liver. Cancer. 1980;46(4):771-9. [PubMed: 6994872].

2. Horie Y, Hori T, Hirayama C, Hashimoto K, Yumoto T, Tanikawa K. Osteoclast-like giant cell tumor of the liver. Acta Pathol Jpn. 1987;37(8):1327-35. [PubMed: 3673575].

3. Rudloff U, Gao ZQ, Fields S, Gecelter GR. Osteoclast-like giant cell tumor of the liver: a rare neoplasm with an aggressive clinical course. J Gastrointest Surg. 2005;9(2):207-14. doi: 10.1016/j.gassur.2004.07.007. [PubMed: 15694816].

4. Bauditz J, Rudolph B, Wermke W. Osteoclast-like giant cell tumors of the pancreas and liver. World J Gastroenterol. 2006;12(48):7878-83.
[PubMed: 17203538].

5. Zhang S. Osteoclast-Like Giant Cell Tumor Of The Liver: A Case Report And Literature Review. Internet J Pathol. 2006;6:1-5.

6. Dahm HH. Immunohistochemical evaluation of a sarcomatoid hepatocellular carcinoma with osteoclastlike giant cells. Diagn Pathol. 2015;10:40. doi: 10.1186/s13000-015-0274-4. [PubMed: 25928039].

7. Kuwano H, Sonoda T, Hashimoto H, Enjoji M. Hepatocellular carcinoma with osteoclast-like giant cells. Cancer. 1984;54(5):837-42. [PubMed: 6331629]. 